\title{
Sobre el desplazamiento por cambio climático y su regulación en el Derecho Internacional
}

\author{
Climate change displacement and \\ its regulation in International Law
}

\author{
Beatriz Felipe Pérez Universidad Rovira i Virgili, España \\ Recibido: 20/7/2020 \\ Aceptado: $\quad$ 17/9/2020 \\ Recibido: 1/9/2020 \\ Aceptado: 18/9/2020 \\ Sumudu Atapattu University of Wisconsin Law School, Estados Unidos \\ Recibido: 9/9/2020 \\ Aceptado : :18/9/2020 \\ Ignacio Odriozola Universidad de Buenos Aires, Argentina \\ Recibido: $\quad 1 / 9 / 2020$ \\ Aceptado: 17/9/2020
}

Matthew Scott Raoul Wallenberg Institute of Human Rights and Humanitarian Law, Lund, Suecia

"Conversar" es la acción de hablar con una o varias personas. En esta sección nos proponemos que especialistas dialoguen por escrito sobre uno de los temas actuales del Derecho internacional: el desplazamiento por cambio climático que afecta a miles de personas en todo el mundo y el vacío normativo en el reconocimiento de la protección de estos desplazados, lo que a su vez genera un debate sobre si considerarlos como migrantes o refugiados. En esta oportunidad invitamos a Josefina Buscetti* quien planteó a los especialistas el siguiente interrogante: el Comité de Derechos Humanos de las Naciones Unidas, a principios del año 2020, en su opinión al caso sobre la deportación a la República de Kiribati de Ioane Teitiota quién había solicitado asilo bajo los términos de "refugiado" o "persona protegida" en Nueva Zelanda, concluyó que los desplazados como consecuencia del cambio climático no deben ser devueltos a su país de origen si sus derechos humanos fundamentales como el derecho a la vida, se encuentran en riesgo a causa de este retorno, marcando de esta manera un precedente a nivel global, por lo tanto, ¿cómo considera que debe plantearse la normativa internacional para que en su aplicación los Estados tengan la obligación de reconocer y proteger a los desplazados transfronterizos por cambio climático que solicitan asilo? A continuación compartimos las opiniones de los especialistas sobre la cuestión planteada.

Palabras clave: cambio climático, desplazamiento, principio de non refoulement

Cómo citar este artículo: $\quad$ Atapattu, S., Felipe Pérez, B., Odriozola, I. y Scott, M. (2020). Sobre el desplazamiento por cambio climático y su regulación en el Derecho Internacional. Revista Electrónica de Derecho Internacional Contemporáneo, 3 (3), 121 - 126. https://doi.org/10.24215/2618303Xe007
* Miembro del Departamento de Derecho Internacional del Instituto de Relaciones Internacionales, Universidad Nacional de La Plata. Correo electrónico: josefinabuscetti@gmail.com 


\section{Beatriz Felipe Pérez}

Investigadora asociada al Centro de Estudios de Derecho Ambiental de Tarragona (CEDAT) de la Universidad Rovira i Virgili (URV, Tarragona). Licenciada de Ciencias Ambientales (Universidad de Granada) y Máster en Derecho Ambiental, Postgrado en Cooperación Internacional y Desarrollo y Doctora en Derecho por la URV. Se ha especializado en temas de migraciones climáticas, cambio climático y educación para la justicia global. Socia co-fundadora de CICrA Justicia Ambiental.

No cabe duda de que, aunque el Comité de Derechos Humanos de las Naciones Unidas (CDH) rechazó la petición del Sr. Teitiota, el Dictamen1 supone un paso adelante en el reconocimiento y la protección jurídica de las personas que huyen de los impactos climáticos cruzando fronteras internacionales (entre otras). El fallo del CDH establece un precedente sobre cómo abordar futuras solicitudes de protección internacional basadas en impactos climáticos. Uno de los aspectos más importantes del Dictamen es que abre la puerta a la aplicación del principio de no devolución (non-refoulement) para ciertos casos de migraciones climáticas internacionales. Es decir, sienta las bases para que los Estados no puedan devolver a su país de origen a las personas cuyo derecho a la vida se vea amenazado por las condiciones climáticas nefastas (párr. 9.11).

Sin embargo, debemos tomarlo con cautela. Para que se llegue a considerar que los impactos climáticos suponen una amenaza al derecho a la vida y así activar el principio de no devolución no basta con que existan condiciones adversas. Pensemos en el caso del Sr. Teitiota, una persona que huyó de Kiribati, entre otros motivos, por la ya evidente escasez de territorio y de agua. En este caso, el CDH entendió que la situación no era tan grave como para considerar que su derecho a la vida se estaba viendo afectado.

Cabe reflexionar sobre el umbral que se debe sobrepasar para que se accione este principio, es decir, cuál deber ser la gravedad de la situación en la que se encuentre una persona para que se entienda que su derecho a la vida se está viendo vulnerado en el contexto de la emergencia climática. El propio CDH reconoce que es probable que el aumento del nivel del mar convierta Kiribati en inhabitable en unos 10-15 años (párr. 9.12), sobre lo que cabe preguntarse si los habitantes de Kiribati -y de otros Estados en situaciones similares- han de permanecer en las islas en condiciones ya peligrosas hasta que la situación sea tan grave como para que puedan ser considerados receptores de protección internacional.

Si bien resulta imprescindible que los Estados adapten su normativa interna relativa al asilo a esta nueva realidad mediante la incorporación de un análisis exhaustivo de las condiciones ambientales y climáticas en la región de la que proviene la persona solicitante, también lo es avanzar en políticas y prácticas jurídicas que protejan a quienes han de abandonar sus hogares en el contexto de la emergencia climática antes de que el daño sea tan grave como para que se llegue a considerar una vulneración del derecho a la vida.

En base a lo anterior, considero que, además de adaptar la normativa internacional para que en su aplicación los Estados tengan la obligación de reconocer y proteger a los desplazados transfronterizos por cambio climático que solicitan asilo es importante, a corto plazo, (1) que los Estados realicen verdaderos esfuerzos para paliar las consecuencias de la crisis climática y (2) avanzar en otro tipo de medidas jurídicas y políticas que sean aplicables cuanto antes y que no requieran que se llegue a una situación tan grave en la que se vulnere el derecho a la vida, ya que las migraciones climáticas están ocurriendo hoy en día en todo el planeta. Un ejemplo sería la adopción de acuerdos migratorios, bilaterales o regionales, o visados que permitan que las personas se trasladen desde los Estados más afectados por los impactos del cambio climático a los que más han contaminado.

1 https://ohrh.law.ox.ac.uk/teitiota-v-new-zealand-a-step-forward-in-the-protection-of-climate-refugees-under-international-human-rights-law/ 


\section{Matthew Scott}

Matthew Scott leads the People on the Move thematic area at the Raoul Wallenberg Institute of Human Rights and Humanitarian Law. Academically, he focuses in particular on the integration of displacement into disaster risk reduction and climate change adaptation law, policy and practice, and currently leads two projects in the Asia-Pacific region focusing on these issues. He also coordinates the Institute's activities relating to refugees and other displaced persons across Africa, Asia-Pacific, Europe and MENA regions, working across research, education, direct engagement and human rights forum modalities. He defended his doctoral thesis in 2018, entitled Refugee Status Determination in the Context of 'Natural' Disasters and Climate Change: A Human RightsBased Approach.

Although the decision of the Human Rights Committee provides important and progressive clarification of the scope of the non-refoulement obligation under Article 6 ICCPR in cases where the risk on return relates to disasters and other adverse impacts of climate change, it does not guarantee that states will extend international protection to people displaced across borders in this context, even where eligibility could be established according to the interpretation set out in Teitiota $\mathrm{v}$ New Zealand.

The progressive aspect of the decision of the HRC relates to the recognition that the non-refoulement obligation applies not only where a person faces an imminent risk of arbitrary deprivation of life on return to the country of origin or habitual residence. It also applies where return entails a foreseeable deprivation of the right to life with dignity, which significantly integrates economic and social rights into the Article 6 assessment. The decision also focuses attention on the conduct of the state seeking to implement an expulsion decision, rather than on whether the conduct of the authorities in the receiving state could be considered in breach of their human rights obligations. Thus, the decision certainly opens a space for legal argument, and it is likely that some individuals will benefit from the decision by securing international protection in the near future. There is certainly scope for promoting engagement with this decision by lawyers as well as authorities responsible for determining claims for international protection. Implementation will be affected by the same politico-economic factors that currently prevent people in need of international protection from receiving it.

As the climate emergency intensifies and the prospect of entire regions becoming uninhabitable loses the veneer of fantasy or mere speculation, it is likely that states will take further steps to avoid international legal obligations through externalization initiatives, together with legal maneuvering to avoid responsibility for people who enter their territory. Indeed, notwithstanding the fact that the international protection system clearly does prevent refoulement in individual cases, the willingness of states to breach either the letter or the spirit of international law relating to non-citizens has been demonstrated time and again in places like Manus Island, the Mediterranean Sea, and the border between Mexico and the USA. This hostile environment is unlikely to disappear and may very well intensify, as a consequence of climate emergency combined with other shocks, including, for instance, pandemics.

The approach promoted in the Nansen Initiative's Agenda for the Protection of Cross-Border Displaced Persons in the Context of Disasters and Climate Change, emphasizing national, bilateral and regional approaches based on the voluntary adoption of 'effective practices' from amongst a broad 'toolkit' of potential measures, is certainly a relevant feature of the landscape, and should be promoted, including through the links established under the Global Compact on Safe, Orderly and Regular Migration. This frame obviously depends on the willingness of states to establish schemes to address cross-border human mobility, although numerous examples do exist.

The agenda reflected in the Global Compacts is heavily focused on states, and there is good reason to look towards alternative responses to human mobility in the 21 st century. In particular, sub-national approaches, including the human rights cities movement and municipal initiatives such as sanctuary cities, warrant closer attention. . 


\section{Sumudu Atapattu}

Sumudu Anopama Atapattu is the Director of Research Centers and Senior Lecturer at UW Law School. She teaches in the area of International Environmental law and climate change and human rights. She holds an LL.M. (Public International Law) and a Ph.D. (International Environmental Law) from the University of Cambridge, U.K., and is an Attorney-at-Law of the Supreme Court of Sri Lanka.

Teitiota $v$. New Zealand ${ }^{l}$ is the first time that a UN human rights body was confronted with the issue of climate refugees. ${ }^{2}$ In his communication, the author, a citizen of the Republic of Kiribati, claimed that New Zealand violated his right to life under the ICCPR by rejecting his application for refugee status and removing him to Kiribati in September $2015 .^{3}$ He claimed that the consequences of climate change including sea level rise forced him to migrate from his home island to New Zealand due to lack of fresh water, land erosion, a housing crisis and violent disputes. ${ }^{4}$

This decision is an important step towards recognizing "climate refugees." However, its application is limited and the decision to admit such refugees rests on individual states. The Committee's decision to reject the communication rested on two main grounds: (a) the threat to the author's right to life was not imminent; and (b) the Republic of Kiribati was actively pursuing adaptation measures. The Immigration and Protection Tribunal of New Zealand laid down an additional ground that Mr. Teitiot failed to establish personal injury. Given the pervasive nature of climate consequences, it is arguable whether it is even possible to establish personal injury above and beyond injury suffered by the rest of the community. ${ }^{5}$

Even though the author's communication was unsuccessful and the threshold to establish a violation was very high, ${ }^{6}$ this decision breaks new ground for several reasons: (a) the Committee recognized that both sudden events and slow onset events can trigger the movement of people, essentially accepting the notion of "climate refugees;" (b) it accepted that climate change could, in extreme situations, affect the right to life, triggering the application of the principle of nonrefoulement; ${ }^{7}$ (c) the Committee also recognized that sea level rise could render the Republic of Kiribati (and, by implication, other small island states) uninhabitable; and (d) it indirectly referred to the obligation of the international community to assist these countries to take affirmative action, including relocating the populations. ${ }^{8}$

States cannot be "forced" to accept any refugees, climate or otherwise. States have established their own laws and procedures in relation to political refugees but a protection gap exists with regard to climate refugees. ${ }^{9}$ Despite the fact that the Committee's views are not binding on states, it is hoped that this decision as well as the work of the Task Force on Climate Displacement, will encourage states to include irreparable harm caused by climate change as a ground for seeking refugee status.

1 Ioane Teitiota v. New Zealand (advance unedited version), CCPR/C/127/D/2728/2016, UN Human Rights Committee (HRC), 7 January 2020, para 8.5, available at: http://blogs2.law.columbia.edu/climate-change-litigation/wp-content/uploads/sites/16/non-us-case-documents/2020/20200107_CCPRC127D27282016-_opinion.pdf

2 See Adaena Sinclair-Blakemore, "Teitiota v New Zealand: A Step Forward in the Protection of Climate Refugees under International Human Rights Law?, 28 January 2020, Oxford Human Rights Hub https://ohrh.law.ox.ac.uk/teitiotav-new-zealand-a-step-forward-in-the-protection-of-climate-refugees-under-international-human-rights-law/

3 Supra note 1

4 Ibid, para 2.1

5 In his individual (dissenting) opinion, Committee Member Duncan Laki Muhumuza stated that the State Party placed an unreasonable burden of proof on the author to establish a real risk and danger of arbitrary deprivation of life under Article 6 of the ICCPR.

6 See Sinclaire-Blakemore, supra note 2

7 Se Jne McAdam, Complementary Protection in International Refugee Law (2007, OUP), and UNHCR, Advisory Opinion, on the Extraterritorial Application of Non-Refoulement Obligations under the 1951 Convention relating to the Status of Refugees and its 1967 Protocol, 26 January 2007, available at: https://www.unhcr.org/4d9486929.pdf

8 Ibid.

9 See Kent and Berhman, Facilitating the Resettlement and Rights of Climate Refugees (Routledge, 2018) 


\section{Ignacio Odriozola}

MSc Migration and Mobility Studies (University of Bristol). Abogado (Universidad de Buenos Aires). Miembro e investigador de la Red Sudamericana para las Migraciones Ambientales (RESAMA). Becario Chevening 2019/2020 (Foreign, Commonwealth and Development Office, Government of the United Kingdom). Se desempeña como abogado en la Comisión del Migrante de la Defensoría General de la Nación (Argentina).

No existe un instrumento global que obligue a los Estados a reconocer y proteger a aquellas personas que solicitan asilo por los efectos del cambio climático. Los motivos son diversos: desde la dificultad de determinar al medioambiente como 'factor de persecución' hasta el repliegue del multilateralismo. ${ }^{1}$ Por ello, bajo las condiciones propuestas en la pregunta formulada (especialmente considerando la 'obligación' que tendrían los Estados), me voy a referir primero a una eventual normativa internacional y luego a los mecanismos existentes pasibles de ser vinculantes.

La potencial normativa internacional que aborde este asunto debería plantearse de modo pragmático y concreto, para proteger a las personas merecedoras de protección internacional como así también para salvaguardar la integridad del instituto del asilo.

Mi propuesta normativa, acompañando aquella de Lister (2014), en vez de ideal busca en lo inmediato ser práctica y facilitar el fin que persigue. Por eso, de manera prioritaria y urgente, debería brindar asilo a aquellas personas que se desplazan de modo permanente por los efectos de evolución lenta e irreversibles del cambio climático y que, debido a la inhabitabilidad del territorio, no cuenten con la posibilidad de desplazarse internamente. Un ejemplo identificable sería aquél de las personas procedentes de pequeños Estados insulares, tales como Kiribati, Tuvalu o Islas Marshall, quienes se ve(rá)n obligadas a desplazarse cruzando una frontera internacional debido al aumento del nivel de los mares y la salinización del agua potable -inter alia- ${ }^{2}$

La normativa en cuestión, además de intangible, debería garantizar principios elementales con carácter absoluto, como el non-refoulement, ${ }^{3}$ y asegurar una serie de derechos que las personas desplazadas perderán por el hecho de abandonar el territorio inhabitable: pueden mencionarse, por caso, el derecho a elegir donde residir (Eckersley, 2015), a la nacionalidad y la autodeterminación de la comunidad desplazada (Ödalen,

1 Otros factores que impiden alcanzar un consenso respecto de una normativa internacional en la materia son la multicausalidad de los procesos migratorios, la variación en la intensidad y en la temporalidad de los factores climáticos y la insuficiencia de información empírica en la materia. Asimismo, debe agregarse que el Alto Comisionado de Naciones Unidas para los Refugiados (ACNUR) rechaza la aplicación de la Convención de Ginebra de 1951 a los efectos de proteger a quienes solicitan asilo como consecuencia del cambio climático. El ACNUR entiende que los motivos de persecución que determinan quién puede ser considerada una persona 'refugiada', según la definición clásica, no incluyen factores medioambientales. De todos modos, es importante aclarar que el posicionamiento del ACNUR no impidió que distintos sistemas judiciales (Australia, Nueva Zelanda, Canadá, entre otros), según revela el interesante trabajo de Matthew Scott, hayan desdoblado la interpretación de la Convención de Ginebra 1951 para considerar que, como consecuencia de factores medioambientales, pueden activarse alguno de los motivos de persecución de la definición clásica. Para más detalles ver:

2 En la obra de Dryzek et. al, Doyle y Chatuverdi señalan que esta medida de adaptación es inevitable dado que se ha demostrado que, aun logrando estabilizar las emisiones de gases de efecto invernadero, el nivel del mar continuará aumentando durante los próximos mil años.

3 El principio de non-refoulement (por su expresión en francés) o 'no devolución', representa una prohibición impuesta a los Estados por el Derecho Internacional de expulsar o devolver a una persona al territorio de cualquier país en el que su vida o su libertad se encuentren amenazadas, o en el que pudiera sufrir tortura, tratos inhumanos o degradantes $u$ otras graves transgresiones de sus derechos humanos fundamentales. El principio representa la piedra angular del Derecho Internacional de los Refugiados, y es está previsto en el artículo 33.1 de la Convención de Ginebra de 1951. También se aplica en el ámbito del Derecho Internacional de los Derechos Humanos -ver nota v-. 
2014), a la cultura (Wewerinke, 2014) e incluso derechos económicos sobre el territorio abandonado (Yamamoto et. al, 2010), entre otros.

Por otra parte, hoy día existen mecanismos de protección respecto de las personas desplazadas transfronterizas por efectos climáticos repentinos y/o temporarios -inundaciones, terremotos, etc-, es decir, buenas prácticas estatales o regionales como la extensión de visas humanitarias o la activación de planes de emergencia. Estas prácticas han sido endorsadas en documentos 'soft law' por diferentes instituciones que inciden en la gobernanza global de las migraciones4 e incluso fueron incluidas en el Objetivo 2 del Pacto Global sobre Migraciones (2018). Sin embargo, carecen de fuerza vinculante y no tienen por objetivo garantizar asilo sino brindar asistencia temporal ante la inminencia del daño que pudiera causar el efecto climático. Por ello, el verdadero reto normativo es extender estas prácticas a nivel internacional, alentando la conciencia de obligatoriedad, y asegurando la posibilidad de que aquellas personas que soliciten asilo puedan acceder a la protección complementaria5 que garantiza el derecho internacional de los derechos humanos, tal como sugiere el caso Ioane Teitiota.

Sea de una u otra forma, el asunto bajo estudio está en pleno desarrollo y para 'no dejar a nadie atrás' el Derecho internacional deberá acompañar este proceso.

Referencias

Doyle, T. \& Chaturvedi, S. (2018). Climate Refugees and Security: Conceptualizations, Categories, and Contestations. En J.S. Dryzek, R.B. Norgaard, and D. Schlosberg (eds), The Oxford Handbook of Climate Change and Security (pp. 279-292) Oxford University Press.

Eckersley, R. (2015). The common but differentiated responsibilities of states to assist and receive 'climate refugees.' European Journal of Political Theory 14(4) pp. 481-500.

Lister, M. (2014). Climate change refugees. Critical Review of International Social and Political Philosophy 17(5) pp. 618-634.

Ödalen, J. (2014). Underwater Self-determination: Sea-level Rise and Deterritorialized Small Island States. Ethics, Policy \& Environment, 17(2) pp. 225-237.

Scott, M. (2020). Climate Change, Disasters, and the Refugee Convention. Cambridge: Cambridge University Press.

Wewerinke, M. (2013). A Right to Enjoy Culture in Face of Climate Change: Implications for Climate Migrants. CGHR Working Paper 6| 4CMR Working Paper 7. Cambridge: University of Cambridge Centre of Governance and Human Rights, pp. 3-15.

Yamamoto, L \& Esteban, M. (2010). Vanishing Island States and sovereignty. Ocean and Coastal Management, 53 (1) pp. 1-9.

\footnotetext{
4 En este sentido, y por mencionar algunas, pueden consultarse en el idioma español el informe presentado en la XVI Conferencia Suramericana sobre Migraciones, titulado 'Migración, medio ambiente y cambio climático: agenda 2030, buenas prácticas y desafíos para la región suramericana', o bien el informe 'Protección de personas que se desplazan a través de fronteras en el contexto de desastres' presentado en la Conferencia Regional de Migraciones, entre otros.

5 Se denomina protección complementaria o subsidiara a los medios que permiten regularizar la permanencia de personas que no son reconocidas como refugiadas pero cuyo retorno sería contrario a obligaciones generales sobre la no devolución, contenidas en diferentes instrumentos de derechos humanos (por ejemplo, artículos 22.8 de la Convención Americana sobre Derechos Humanos, 7 del Pacto Internacional de Derechos Civiles y Políticos, 3 de la Convención contra la Tortura y otros Tratos o Penas Crueles, Inhumanos o Degradantes, 13 de la Convención Interamericana para prevenir y sancionar la tortura...).
} 